\title{
Determination of Harvest Maturity for Mango (Mangifera indica L.) Fruit by Non-Destructive Criteria
}

\author{
Moomin Abu1 ${ }^{*}$, Nana Sakyiwa Olympio², Joseph Ofei Darko³ \\ ${ }^{1}$ Department of Horticulture, Faculty of Agriculture, University for Development Studies, Nyankpala, Tamale, Ghana \\ ${ }^{2}$ Department of Horticulture, Kwame Nkrumah University of Science and Technology, Kumasi, Ghana \\ ${ }^{3}$ Department of Agricultural Engineering, Kwame Nkrumah University of Science and Technology, Kumasi, Ghana \\ Email: ^moonabu@yahoo.com
}

How to cite this paper: Abu, M., Olympio, N.S. and Darko, J.O. (2021) Determination of Harvest Maturity for Mango (Mangifera indica L.) Fruit by Non-Destructive Criteria. Agricultural Sciences, 12, 1103-1118 https://doi.org/10.4236/as.2021.1210071

Received: September 5, 2021

Accepted: October 15, 2021

Published: October 18, 2021

Copyright $\odot 2021$ by author(s) and Scientific Research Publishing Inc. This work is licensed under the Creative Commons Attribution International License (CC BY 4.0).

http://creativecommons.org/licenses/by/4.0/

\begin{abstract}
Haden, Kent, Palmer, and Keitt mango varieties were studied to establish the relationship of harvest time to 1) seasonal accumulated day-degrees or heat units $\left.\left({ }^{\circ} \mathrm{C}\right), 2\right)$ daily rainfall amount $(\mathrm{mm})$, and 3$)$ physical fruit development attributes in order to fix maturity standards for export and local markets. Randomized Complete Block Design with four replications was used. In each case of Haden, Kent, Palmer, and Keitt varieties, physical fruit development attributes established as standard harvest maturity values were: weight $(640 \mathrm{~g}$, $836 \mathrm{~g}, 837 \mathrm{~g}$, and $1104 \mathrm{~g}$, respectively), length $(16.31 \mathrm{~cm}, 16.19 \mathrm{~cm}, 21.22 \mathrm{~cm}$, and $19 \mathrm{~cm}$, respectively), width $(30.97 \mathrm{~cm}, 33.47 \mathrm{~cm}, 30.86 \mathrm{~cm}$, and $35.91 \mathrm{~cm}$, respectively), volume $\left(598 \mathrm{~cm}^{3}, 807 \mathrm{~cm}^{3}, 772 \mathrm{~cm}^{3}\right.$, and $959 \mathrm{~cm}^{3}$, respectively), density $\left(1.147 \mathrm{~g} / \mathrm{cm}^{3}, 1.076 \mathrm{~g} / \mathrm{cm}^{3}, 1.084 \mathrm{~g} / \mathrm{cm}^{3}\right.$, and $1.189 \mathrm{~g} / \mathrm{cm}^{3}$, respectively), and indentation $(0.25 \mathrm{~cm}, 0.49 \mathrm{~cm}$, and $0.50 \mathrm{~cm}$, respectively). The intensity of grooves around the stylar-scar end of Palmer fruits was studied and used as maturity index. Index values of $0.075 \mathrm{mls}, 0.150 \mathrm{mls}, 0.425 \mathrm{mls}$, and 0.116 mls, respectively, for Haden, Kent, Palmer, and Keitt varieties were recorded as latex exuded at harvest since these values tallied with the other physical harvest maturity index values, and also with those of rain fall and temperature values. Temperature, rainfall, and physical characteristics are therefore important non-destructive criteria for fixing maturity index values for mango fruits.
\end{abstract}

\section{Keywords}

Harvest Maturity, Mango Fruit, Non-Destructive, Criteria

\section{Introduction}

Mango is touted as "the next big crop in Ghana" with the potential to replace 
cocoa as the nation's most valuable cash crop. As a fruit crop is grown widely in the country, mango has been found to be of commercial value, and over the years there has been widespread interest in its cultivation not only by development agencies under various environmental protection and poverty reduction programmes, but also by private individuals and companies who are into mango export [1]. The Centre for the Promotion of Imports from Developing Countries [2] market survey earlier on reported that the mango fruit is one of the most highly esteemed fruits of the tropics. The importance of mango is epitomized in the description for the crop as "golden tree", "next cash crop", "gold mine", and "Ghana's future" [3].

A European Union Strategic Marketing Guide [4] report indicated that many countries in Africa, South America, and Asia have become aware of the possibility to penetrate the market for mango in Europe. According to the report favourable climatic conditions and low labour cost led to low production cost and gave the South American and African countries strong position on the European markets. The report further stated that if Ghana was compared to some of the countries in the southern region, Ghana was closer to Europe and thus had the urge in terms of market opportunities due to low transportation cost and short delivery times. With all these opportunities, Ghana was still unable to take advantage due to the uncompetitive state of the mango industry. Findings by Abu et al. [5] on a study of the mango industry in Ghana indicated overwhelmingly among other challenges, that mango farmers in Ghana had difficulty in determining appropriate harvest maturity stage that could be standardized for an enhanced storage life of the fruit. According to Okorley et al. [1] lack of simple and reliable methods for determining appropriate stage of fruit maturity affected quality, and that one of the major problems that restricted international trade in mango was the variation in physiological maturity in a single consignment.

Marques et al. [6] outlined two important measures of fruit maturity viz., 1) legal minimum standard of maturity and 2) horticultural maturity. According to these authors legal minimum standards rely on the application of a prescribed test e.g. tests on dry matter level and fruit flesh colour which confirms the acceptance of the fruit for consumption or processing when ripe. These authors added that assessment of horticultural maturity relies on prescribed tests to assess product suitability for more stringent quality specifications such as may be required for contract sales or export. In both cases, easy-to-assess harvest indices via visual attributes are needed and they must correlate with the recognized variables measured in prescribed tests [6]. These authors added that workers who harvest and grade fruit should be trained and tested for their ability to accurately select fruit according to the preferred non-destructive index. Visual assessment of maturity is complicated by the fact that cultivars differ and fruits on the same tree may vary significantly in maturity levels due to prolonged or uneven flowering times [6].

Okorley et al. [1] indicated that fruit maturity was an important factor that 
determined fruit quality in overseas markets. If fruits in a consignment were of uneven maturity, it would be impossible to find an effective storage regime which would ensure good quality on arrival. One fruit of more advanced maturity in a consignment could accelerate the ripening of all fruit, resulting in symptoms of malady and consequent short storage life [1]. Kouno et al. [7] earlier on reiterated that future research should consider easy-to-apply harvest indices and non-destructive methods for checking fruit maturity which could be incorporated in an automated grading system.

Variation in maturity among fruits could also be influenced by the specific location of fruit on the tree. In the southern hemisphere, fruit on the northern side mature more quickly than fruit on the southern side [8]. Harvesting at optimum maturity is a critical step that determines the potential storage life, flavour, aroma, and consumer acceptance of mango fruits [9]. Immature fruits were more prone to mechanical damage and also more susceptible to certain postharvest maladies such as chilling injury which caused uneven ripening with less skin colour development and consequently affected quality when ripe [10] [11]. On the other hand, over-maturation of fruit resulted in aggravation of physiological disorders such as internal breakdown [12]. The advanced maturation of mango on the tree resulted in better aroma quality including lower sugar/acid ratio [6], but reduced storage potential [13]. Thus, optimum harvest maturity determines the suitability of fruit for appropriate postharvest handling. But harvesting decisions by growers and buyers are generally biased towards achieving longer storage life by harvesting prior to the appropriate maturity stage which makes the determination of optimum harvest maturity remain a debatable question. Application of a plethora of maturity indices including morphological, computational methods, chemical attributes, physical attributes, and some non-invasive methods such as near-infrared spectroscopy and ultrasonic waves have been suggested to judge fruit maturation [14]. Therefore, the objective of the study was to determine the appropriate harvest maturity stage for mango fruit by non-destructive means in order to fix standards of maturity for harvesting. This was done through the assessment of mango fruit physical/external attributes, accumulated seasonal day-degrees or heat units $\left({ }^{\circ} \mathrm{C}\right)$, and rainfall $(\mathrm{mm})$ measurements up to physiological maturity.

\section{Materials and Methods}

\subsection{Experimental Site, Period, and Plant Materials}

Field studies were conducted on Haden, Kent, Palmer, and Keitt mango varieties to determine the fruits' harvest quality attributes in order to fix standards of maturity for harvesting. This was done through computational methods using day-degrees or heat units $\left({ }^{\circ} \mathrm{C}\right)$ and rainfall $(\mathrm{mm})$ measurements, and physical/external attributes of fruit development and maturation. These were major export mango varieties which were appreciated by importers of mango from Ghana [1] [3] [15]. The study was conducted at Prudent Export and Import 
Company Limited mango plantation in the Somanya-Dodowa mango production zone of the Dangme West District of Greater Accra Region of Ghana. Two major (April to July) and two minor (December to February) seasons were used for the experimental period. Randomized Complete Block Design (RCBD) was used with four replications.

\subsection{Sampling and Determination of Optimum Harvest Maturity by Non-Destructive Methods}

For each of Haden, Kent, Palmer, and Keitt mango varieties, five mango trees were sampled at random in each of the four replications. Date of flower bud initiation was noted on each sample tree. On each sample tree, ten initiated flower buds were also sampled and tagged. Dates of flower initiation and of fruit-set were recorded and the samples tagged accordingly. Regular visual observation (inspection), photographing, and measurement of fruit development characteristics/attributes were carried out at fortnightly intervals from fruit-set up to physiological (pre-climacteric stage) maturity (green-hard, outgrown shoulders, pit around the stalk-end, turning yellow or showing an apparent break of yellow colour in the pulp/flesh) to identify the external indicators (weight, length, width, volume, density (specific gravity), indentation, and exudes of latex) of maturation. In each case of the four varieties, five fruits were randomly sampled per tree on fortnightly basis for the assessment and determination of fruit weight (g) using an electronic balance; fruit length $(\mathrm{cm})$ by measuring the outer curve of the fruit with a tape measure from the distal end to the proximal end where the pulp is judged to terminate [16]; fruit width/girth $(\mathrm{cm})$ by measuring the widest midpoint of each of the five sampled fruits using a tape measure [17]; fruit volume $\left(\mathrm{cm}^{3}\right)$ by direct volume displacement i.e. weighing fruit under water as outlined by Dadzie and Orchard [17]; fruit density (specific gravity) $\left(\mathrm{g} / \mathrm{cm}^{3}\right)$ by dividing the fruit weight in air by the fruit volume; fruit indentation depth $(\mathrm{cm})$ to determine the depth of the pit developed around the pedicel at the proximal end; exudes of latex $(\mathrm{ml})$ by harvesting/cutting the fruit at shoulder-level of the pedicel and the volume of the exuded latex measured in a graduated vial $(\mathrm{ml})$; and the intensity of ridges/grooves around the stylar-scar end of fruits in the case of Palmer [18]: as non-destructive measurements of fruit development and maturation characteristics/attributes. The average measurement of the five fruits represented the value of the particular fruit maturity index parameter of the variety assessed at a time. Total heat units and total rainfall values obtained during fruit development were determined by the sum of the accumulated seasonal daily heat units $\left({ }^{\circ} \mathrm{C}\right)$ and daily rainfall $(\mathrm{mm})$ values, respectively, from flower bud initiation through fruit-set to physiological maturity [19].

\subsection{Statistical Analysis}

All data were analysed using the Analysis of Variance (ANOVA) technique [20] with the GENSTAT statistical program. Least Significant Difference (LSD) at 5\% 
probability was used to determine treatment differences among varieties. Separate analyses were carried out with the data for each of the seasonal trials. The errors for these ANOVAS were tested for homogeneity of variances [20] and found to be statistically not different at $\mathrm{P}>0.05$, so the results for the seasonal experiments were pooled for analysis.

\section{Results}

\subsection{Physical Means of Determining Appropriate Mango Fruit Harvest Maturity}

Keitt fruit had the highest mean weight of $1104 \mathrm{~g}$, while Haden had the lowest mean weight of $640 \mathrm{~g}$ (Figure 1). Weight of Keitt fruit was significantly ( $\mathrm{P}<$ $0.05)$ higher than the fruit weight of the other varieties. There was no significant $(\mathrm{P}>0.05)$ difference in weight between fruits of Palmer $(837 \mathrm{~g})$ and fruits of Kent $(836 \mathrm{~g})$ but weight of fruit in each case of these two varieties was significantly $(\mathrm{P}<0.05)$ higher than that of Haden (Figure 1$)$.

At physiological maturity, fruit of Palmer was longer $(21.22 \mathrm{~cm})$ than fruits of the other varieties. Kent fruit was the shortest $(16.19 \mathrm{~cm})$ but was not significantly $(\mathrm{P}>0.05)$ different from that of Haden $(16.31 \mathrm{~cm})$. Keitt had moderately long fruits $(19 \mathrm{~cm})$ (Figure 2).

At physiological maturity fruit width of Keitt was the widest $(35.91 \mathrm{~cm})$ and was significantly $(P<0.05)$ different from the other varieties. Fruit of Palmer had the smallest width $(30.86 \mathrm{~cm})$ which was significantly $(\mathrm{P}<0.05)$ different from that of Kent $(33.47 \mathrm{~cm}$ ) but not Haden $(30.97 \mathrm{~cm}$ ) at $\mathrm{P}>0.05$ (Figure 3).



Figure 1. Changes in average weight (g) during development and maturation of Haden, Kent, Palmer, and Keitt mango fruits. Bars show standard error of differences of means. Each value represents the mean of four independent determinations at $95 \%$ confidence interval of the variable. 


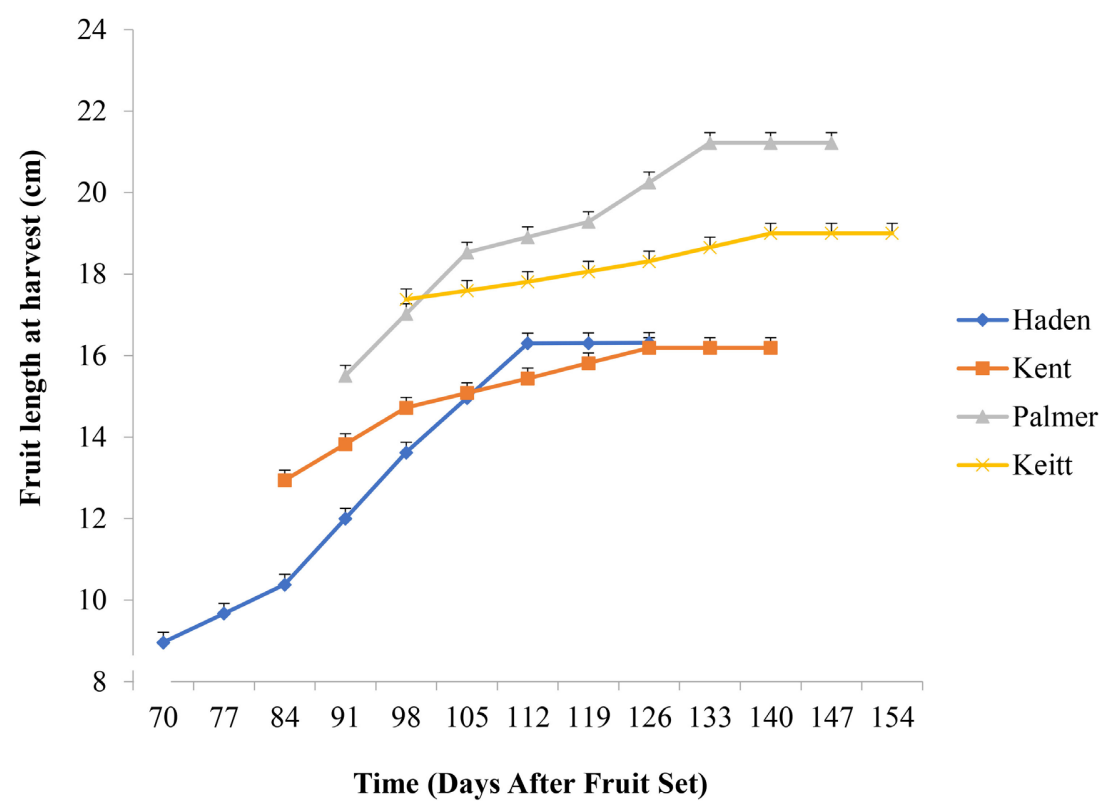

Figure 2. Changes in average length $(\mathrm{cm})$ during development and maturation of Haden, Kent, Palmer, and Keitt mango fruits. Bars show standard error of differences of means. Each value represents the mean of four independent determinations at $95 \%$ confidence interval of the variable.

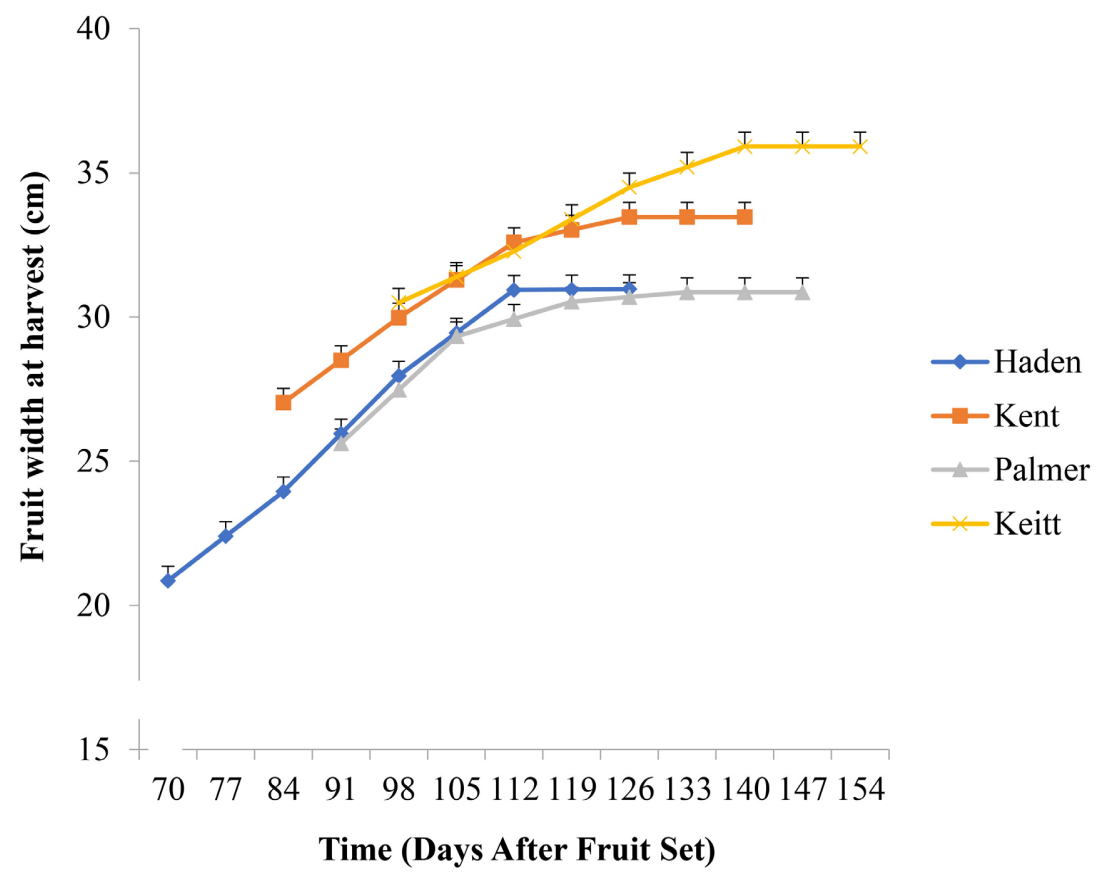

Figure 3. Changes in average width $(\mathrm{cm})$ during development and maturation of Haden, Kent, Palmer, and Keitt mango fruits. Bars show standard error of differences of means. Each value represents the mean of four independent determinations at $95 \%$ confidence interval of the variable.

Fruit volume was significantly $(\mathrm{P}<0.05)$ greater for the Keitt variety (959 $\mathrm{cm}^{3}$ ) than the other varieties at physiological maturity. The lowest volume was 
recorded for Haden $\left(598 \mathrm{~cm}^{3}\right)$. Average volume of fruit for Kent $\left(807 \mathrm{~cm}^{3}\right)$ and Palmer $\left(772 \mathrm{~cm}^{3}\right)$ were not significantly $(\mathrm{P}>0.05)$ different but each of them was significantly $(\mathrm{P}<0.05)$ higher than that of Haden (Figure 4$)$.

In all the four varieties, substantive density index quantities greater than 1.0 $\mathrm{g} / \mathrm{cm}^{3}$ occurred at physiological maturity. Subsequently, fruits in each case of the different varieties showed no significant differences at $\mathrm{P}>0.05$ in density readings (Figure 5).

Fruit density values were highest for Keitt $\left(1.189 \mathrm{~g} / \mathrm{cm}^{3}\right)$ and lowest for Kent $\left(1.076 \mathrm{~g} / \mathrm{cm}^{3}\right)$ at physiological maturity stage (Figure 5). Fruit density of Haden $\left(1.147 \mathrm{~g} / \mathrm{cm}^{3}\right)$ was significantly $(\mathrm{P}<0.05)$ higher than those of Kent $(1.076$ $\left.\mathrm{g} / \mathrm{cm}^{3}\right)$ and Palmer $\left(1.084 \mathrm{~g} / \mathrm{cm}^{3}\right)$ but differences in density between Kent and Palmer were not significant at $\mathrm{P}>0.05$ (Figure 5). Fruit density of Keitt increased drastically between 98 days after fruit set and 112 days after fruit set, after which there was a gradual increment up to physiological maturity (Figure 5).

Fresh fruit latex-flow continued even after physiological maturity but at a decreasing rate (Figure 6). Initially and particularly for the first sampling, the quantity of latex exuded was significantly $(\mathrm{P}<0.05)$ higher for Haden and Palmer fruits than for Kent and Keitt fruits. However, latex emission for Haden decreased significantly $(\mathrm{P}<0.05)$ towards physiological maturity than for Palmer, Kent, and Keitt fruits. At physiological maturity, Palmer fruits emitted significantly $(\mathrm{P}<0.05)$ higher quantities of latex $(0.43 \mathrm{ml})$ than the other varieties while Haden fruits emitted the lowest $(0.08 \mathrm{ml})$ quantity of latex. The quantity of

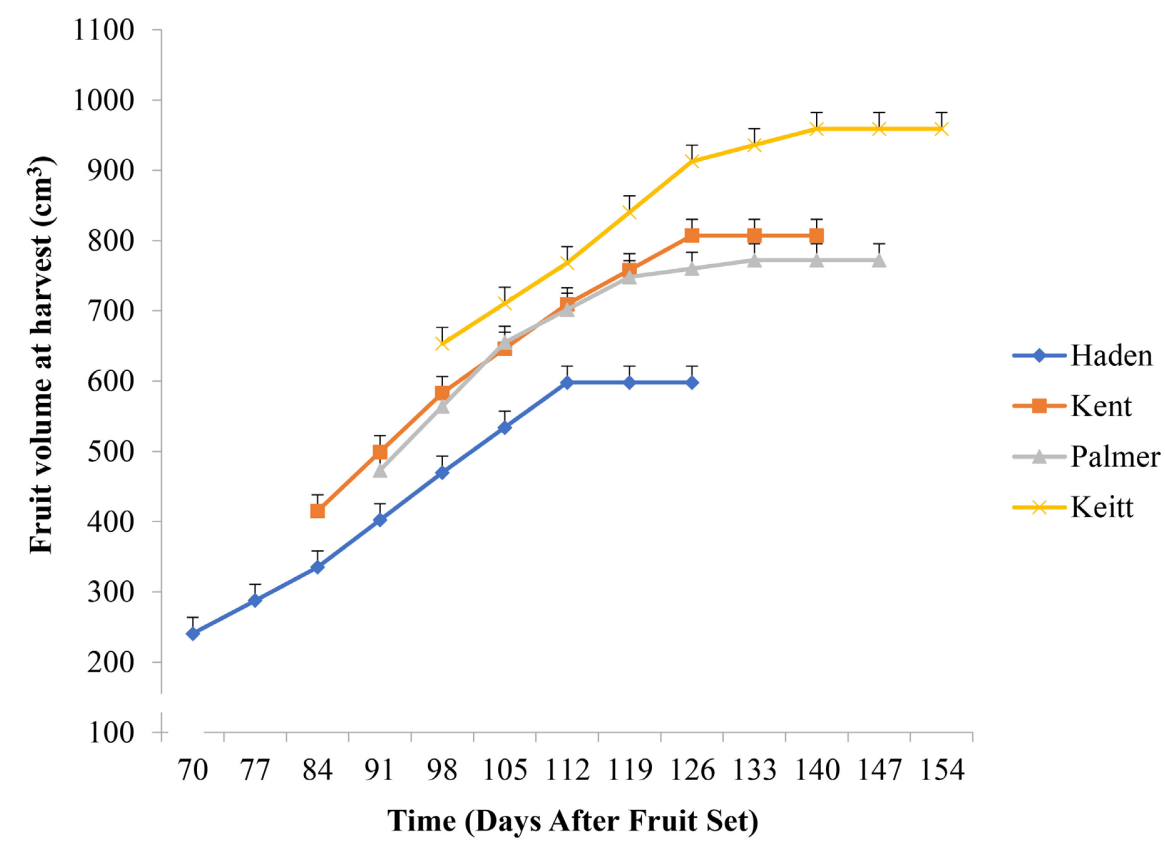

Figure 4. Changes in average volume $\left(\mathrm{cm}^{3}\right)$ during development and maturation of Haden, Kent, Palmer, and Keitt mango fruits. Bars show standard error of differences of means. Each value represents the mean of four independent determinations at $95 \%$ confidence interval of the variable. 


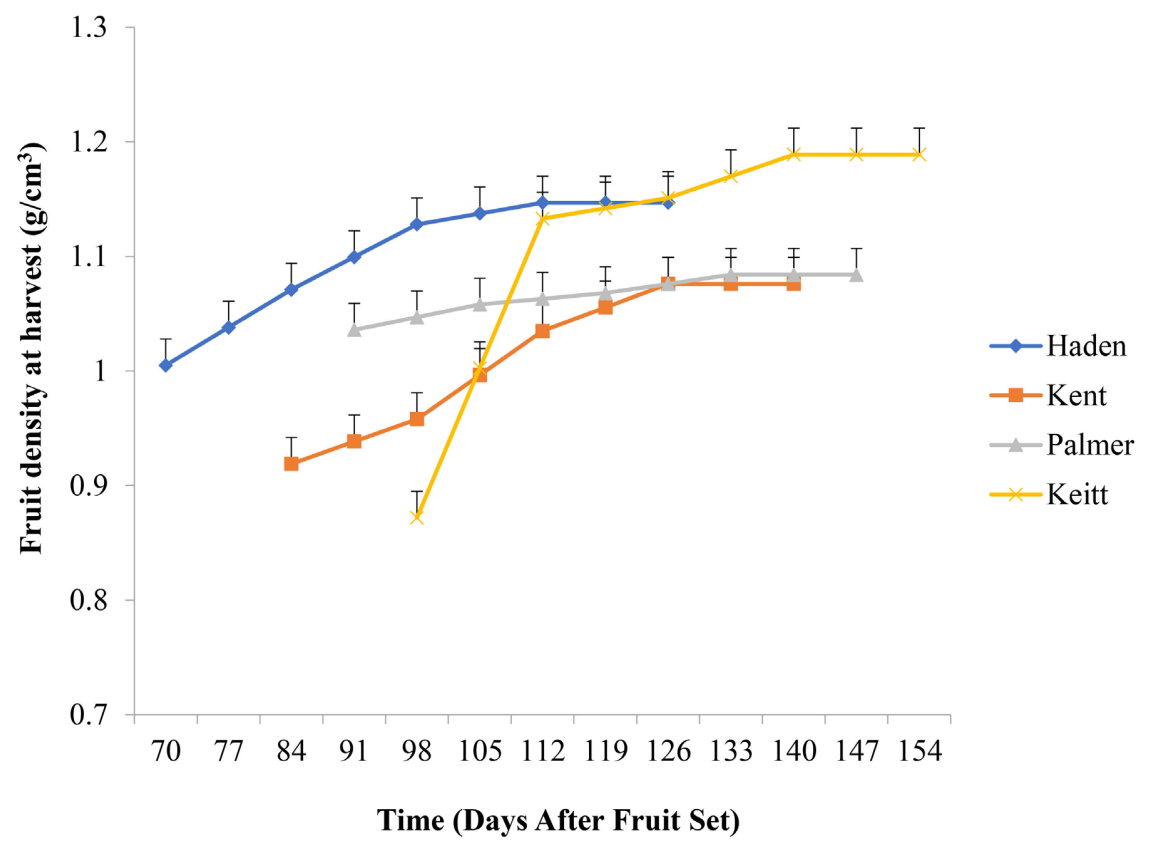

Figure 5. Changes in average density $\left(\mathrm{g} / \mathrm{cm}^{3}\right)$ during development and maturation of Haden, Kent, Palmer, and Keitt mango fruits. Bars show standard error of differences of means. Each value represents the mean of four independent determinations at $95 \%$ confidence interval of the variable.



Figure 6. Changes in average quantity of latex exuded (ml) during development and maturation of Haden, Kent, Palmer, and Keitt mango fruits. Bars show standard error of differences of means. Each value represents the mean of four independent determinations at $95 \%$ confidence interval of the variable.

latex emitted by Kent $(0.15 \mathrm{ml})$ was significantly $(\mathrm{P}<0.05)$ different from that of Haden $(0.08 \mathrm{ml})$ but not that of Keitt $(0.12 \mathrm{ml})$ (Figure 6). 
Rate of change in fruit indentation-depth or outgrown shoulders during fruit development to physiological maturity was quite steady for Keitt and Kent varieties, very slow for Haden fruit, and naturally absent for the Palmer fruit (Figure 7). Keitt and Kent fruits had more indentation depths or outgrown shoulders $(0.50 \mathrm{~cm}$ and $0.49 \mathrm{~cm}$ respectively) at physiological maturity. These were statistically similar, but each of them was significantly $(\mathrm{P}<0.05)$ different from that of Haden $(0.25 \mathrm{~cm})$. Fruits of Haden were, however, moderately indented/shouldered while Palmer fruit had no indentation depth or outgrown shoulders at all (Figure 7 and Plate 1). Unlike Keitt, Kent, and Haden fruit, fruit indentation-depths are manifested by increasing intensity of ridges or grooves around the stylar-scar end of the Palmer fruit (Plate 1).

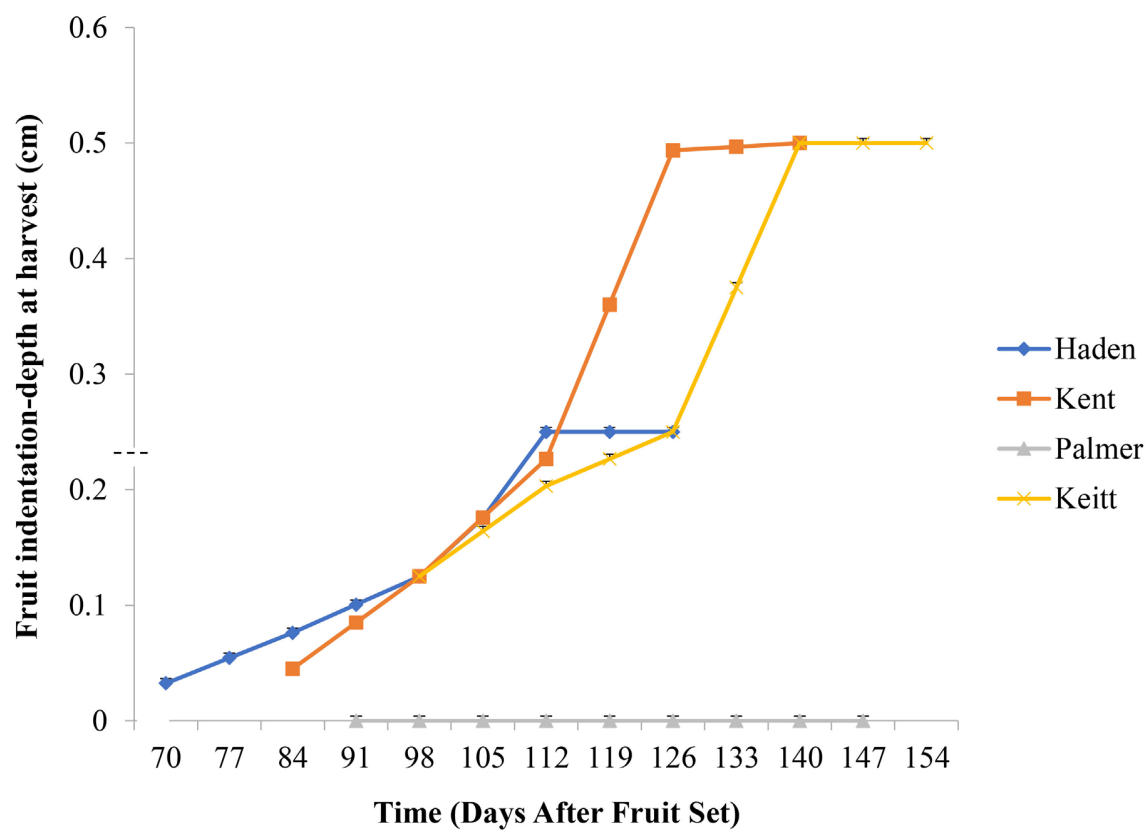

Figure 7. Changes in average indentation-depth $(\mathrm{cm})$ during development and maturation of Haden, Kent, Palmer, and Keitt mango fruits. Bars show standard error of differences of means. Each value represents the mean of four independent determinations at $95 \%$ confidence interval of the variable.

\section{Stage 1}

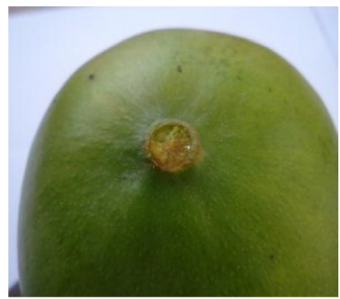

Palmer (91 days from fruit set)
Stage 2



Palmer (105 days from fruit set)
Stage 3

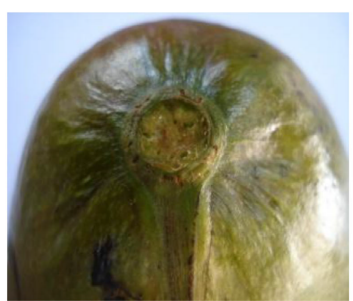

Palmer (119 days from fruit set)
Stage 4

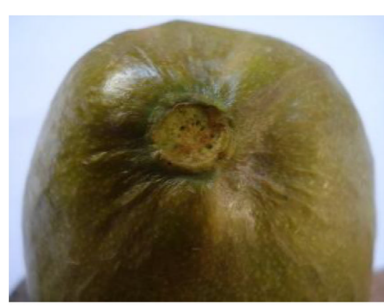

Palmer (133 days from fruit set)

Plate 1. Changes in ridge/groove formation around the stylar-scar end of Palmer mango fruit by stage of fruit development. 


\subsection{Accumulated Seasonal Day-Degrees or Daily Heat Units $\left({ }^{\circ} \mathrm{C}\right)$ and Daily Average Rainfall ( $\mathrm{mm}$ ) Data for Optimum Development of Haden, Kent, Palmer, and Keitt Mango Fruits from Flower Bud Initiation through Fruit Set to Physiological Maturity}

For the major and minor seasons, the accumulated day-degrees $\left({ }^{\circ} \mathrm{C}\right)$ for Haden, Kent, Palmer, and Keitt fruits were $3850.88^{\circ} \mathrm{C}, 4203.33^{\circ} \mathrm{C}, 4366.78^{\circ} \mathrm{C}$, and $4554.66^{\circ} \mathrm{C}$; and $3305.83^{\circ} \mathrm{C}, 4007.20^{\circ} \mathrm{C}, 4207.95^{\circ} \mathrm{C}$, and $4409.02^{\circ} \mathrm{C}$, respectively. The different accumulated heat units during the development of Kent, Palmer, and Keitt fruits were statistically similar but those of Palmer and Keitt fruits were significantly $(\mathrm{P}<0.05)$ different from that of Haden fruits. Heat units accumulated for the development of Kent fruits was not different from that of $\mathrm{Ha}-$ den fruits. This trend was the same for both seasons (Table 1).

Accumulated daily average rainfall data required for optimum development of Haden, Kent, Palmer, and Keitt fruits from flower bud initiation through fruit set to physiological maturity were determined to be $480.36 \mathrm{~mm}, 564.68 \mathrm{~mm}$, $587.24 \mathrm{~mm}$, and $608.55 \mathrm{~mm}$; and $469.80 \mathrm{~mm}, 529.03 \mathrm{~mm}, 548.31 \mathrm{~mm}$, and $567.03 \mathrm{~mm}$, for the major and minor seasons, respectively. The trend of rainfall and the accumulated heat units was similar for all the varieties, i.e., the higher the rainfall amount and accumulated heat units the longer the duration of fruit development to harvest maturity or physiological maturity, and vice versa (Table 1).

\section{Discussion}

Haden, Kent, Palmer, and Keitt mango varieties all come into production or are in crop during both the major and minor seasons annually, in the SomanyaDodowa mango production zone in Ghana irrespective of the differences in their

Table 1. Accumulated seasonal day-degrees or daily heat units $\left({ }^{\circ} \mathrm{C}\right)$ and daily average rainfall $(\mathrm{mm})$ data for optimum development of Haden, Kent, Palmer, and Keitt mango fruits from flower bud initiation through fruit set to physiological maturity.

\begin{tabular}{ccccc}
\hline \multirow{2}{*}{ Mango Variety } & \multicolumn{3}{c}{ Heat units $\left(\right.$ day-degrees $/{ }^{\circ} \mathrm{C}$ ) and average rainfall $(\mathrm{mm}$ ) data } \\
\cline { 2 - 5 } & \multicolumn{2}{c}{ Heat Units $\left(\right.$ day-degree/ ${ }^{\circ} \mathrm{C}$ ) } & \multicolumn{3}{c}{ Average Rainfall (mm) } \\
\hline $\begin{array}{c}\text { Major Season } \\
\text { (mid-April to } \\
\text { mid-August) }\end{array}$ & $\begin{array}{c}\text { Minor Season } \\
\text { (mid-Dec. to } \\
\text { mid-March) }\end{array}$ & $\begin{array}{c}\text { Major Season } \\
\text { (mid-April to } \\
\text { mid-August) }\end{array}$ & $\begin{array}{c}\text { Minor Season } \\
\text { (mid-Dec. to } \\
\text { mid-March) }\end{array}$ \\
\hline Haden & 3850.88 & 3305.83 & 480.36 & 469.80 \\
Kent & 4203.33 & 4007.20 & 564.68 & 529.03 \\
Palmer & 4366.78 & 4207.95 & 587.24 & 548.31 \\
Keitt & 4554.66 & 4409.02 & 608.55 & 567.03 \\
LSD (0.05) & 475.34 & 763.70 & 89.36 & 67.02 \\
\hline
\end{tabular}

Each value represents the mean of four independent determinations at $95 \%$ confidence level/interval of each variable. 
maturity periods. This suggested that importers had the opportunity to choose from a wide variety of mangoes exported from Ghana and as well had the opportunity to do importation in two seasons annually [15]. Mangoes grown in the different seasons did not primarily display any significant variation in any of the physical and climatic attributes tested when seasonal averages were compared, suggesting that the season of production had insignificant influence on most of the physical and climatic attributes on mangoes grown in Ghana.

The rate of development of Haden, Kent, Palmer, and Keitt mango fruits in the present study appeared to take the form of a simple sigmoid pattern which also agreed with the observations made by Nandi et al. [21] and Naik et al. [22]. At physiological maturity, fruits in each case of the different varieties showed no significant differences at $\mathrm{P}>0.05$ in weight, length, width, volume, density, and indentation depth which could be used as standards of maturity for harvesting. Similar observation had been made by Zhang et al. [23] and Raut and Bora [24]. Singh et al. [25] noted that physicochemical determinants such as stabilization of fruit weight, length, width, volume, density, indentation depth, latex content, and starch concentration served as a guide to indicate appropriate harvest time for mango fruit.

All the varieties studied portrayed the recommended sizes of the export fruit quality as defined by the Codex Standards for mango fruits [4] [26]. According to Nandi et al. [21] and Naik et al. [22], recommended size of fruit played a multiple role in its usage including fresh market demands and industrial selection for processing. Abu [27] earlier on recommended the Keitt mango variety for the processing industry since fruits of the variety are bulky (widest width of $35.91 \mathrm{~cm}$ and highest mean weight of $1104 \mathrm{~g}$ ).

Krishnapillai and Wijeratham [28] indicated that the concentration of tannins decreased with maturity as a result of polymerization which is associated with the disappearance of latex. In the present study, index values for the minimal acceptable harvest maturity for fruits of Haden, Kent, Palmer, and Keitt mango varieties with respect to latex content were $0.075 \mathrm{ml}, 0.150 \mathrm{ml}, 0.425 \mathrm{ml}$, and $0.116 \mathrm{ml}$, respectively, since these results tallied with the other acceptable harvest maturity indices viz. fruit weight, length, density, volume, and width. In mango fruit, however, latex flow does not stop entirely at harvest at physiological maturity stage but reduces in flow rate and quantity along the harvest and pack-house processes with time [27]. On-tree ripe fruits, however, show complete disappearance of latex flow or exudation at harvest. These fruits also develop better flavour, quality, and colour; though undesirable in some respects since such fruits are more susceptible to spoilage by birds and other rodents and also do not keep long in storage, and hence in transit [29] [30]. Parthasarathy [31] noted that mango fruits that secrete little to no latex after harvest enhance fruit acceptability and also allow for easier fruit handling since the latex is corrosive and damages the fruit surface and can as well cause irritation on human skin when in contact. Thus, for safe and easier handling of fruits, Haden and Keitt 
fruits which secrete comparatively less latex at harvest may be the favoured varieties.

Iqbal [32] and Abu [27] reported that fruits of some physiologically mature mango varieties showed indentation, depressions with ridges or grooves at the stylar-scar end, and were firm and green. However, since these indices do not apply to all cultivars/varieties [27] [32], they must be considered with other maturity indicators such as fruit weight, length, width, volume, density (specific gravity), exudes of latex, day-degrees $\left({ }^{\circ} \mathrm{C}\right)$, and rainfall data $(\mathrm{mm})$ as in the present study. Penchaiya et al. [13] and Ledesma et al. [33] reiterated that the physiological maturity stage that occurs just before the climacteric rise in respiration, would appear to be a suitable stage of harvest maturity for optimum transport and storage.

The accumulated seasonal day-degrees $\left({ }^{\circ} \mathrm{C}\right)$ recorded for optimum development of fruits from flower bud initiation through fruit set to physiological maturity during the experimental period indicated that a range of $3850.9^{\circ} \mathrm{C}$ $4203.3^{\circ} \mathrm{C}$ heat units was conducive for optimum development of Haden and Kent fruits while a range of $4203.3^{\circ} \mathrm{C}-4554.7^{\circ} \mathrm{C}$ was conducive for the growth of Kent, Palmer, and Keitt mango fruits for the major season. Thus, according to the accumulated seasonal day-degrees $\left({ }^{\circ} \mathrm{C}\right)$ records Kent fruits could grow favourably at all the two temperature ranges. For the minor season, a range of $3305.8^{\circ} \mathrm{C}-4007.2^{\circ} \mathrm{C}$ was conducive for Haden and Kent mango fruits while a range of $4007.2^{\circ} \mathrm{C}-4409.0^{\circ} \mathrm{C}$ was conducive for Kent, Palmer, and Keitt mango fruits. Again, the accumulated seasonal day-degrees $\left({ }^{\circ} \mathrm{C}\right)$ records implied that Kent fruits could grow favourably at both temperature ranges. Litz [34] reported that temperature influenced fruit maturity and quality and that temperature could also influence the suitability of the production area for mango cultivation and harvest period. The author noted that the minimum temperature (base temperature) at which mango will not develop normally was $17.9^{\circ} \mathrm{C}$; whereas Hatfield and Prueger [8] ascribed the abnormal vegetative growth and flowering responses of several mono-embryonic and poly-embryonic cultivars to four temperature regimes ranging from vegetative inductive $\left(30^{\circ} \mathrm{C}\right.$ for day and $25^{\circ} \mathrm{C}$ for night) to floral inductive $\left(15^{\circ} \mathrm{C}\right.$ for day and $10{ }^{\circ} \mathrm{C}$ for night).

The accumulated seasonal rainfall data ranges recorded for optimum development of mango fruits from flower bud initiation through fruit set to harvest maturity during the experimental period indicated that a range of 480.36 $564.68 \mathrm{~mm}$ was conducive for the development of Haden and Kent fruits while a range of $564.68-608.55 \mathrm{~mm}$ was conducive for the development of Kent, Palmer, and Keitt mango fruits for the major season. Thus, according to the accumulated seasonal rainfall data records, Kent fruits could perform favourably at all the two rainfall data ranges. For the minor season, a range of $469.80-529.03$ $\mathrm{mm}$ of the accumulated rainfall data was conducive for Haden and Kent mango fruits while a range of 529.03 - $567.25 \mathrm{~mm}$ was conducive for Kent, Palmer, and Keitt mango fruits. Again, the accumulated seasonal rainfall data records for the 
minor season implied that Kent fruits could grow favourably at both rainfall ranges. According to Slaven [35], the amount and distribution of rainfall determine the suitability of a region for growing mango. This author added that latitude, elevation, nearby water, ocean currents, topography, vegetation, and prevailing winds influence the maturation and quality of the mango fruit. Ledesma et al. [33] reported that mango growth was generally successful when the annual rainfall data ranged between 75 and $350 \mathrm{~mm}$ without water-logging, and where rain did not fall during flowering, fruit set, and fruit development. Differences in rain fall as well as in temperature data occurred during the experimental period but were statistically similar, most probably attributable to the climatic location of the study area. According to Abu [27], differences in rainfall data as well as in temperature data recordings occurred when data in each case of the major and minor seasons' studies were compared during an experimental period but the differences were not significant at $\mathrm{P}>0.05$, and that the differences were most probably attributable to the climatic location of the study area.

The two mango production seasons in the study area could be associated to the marked dry spells that occur between July and August and between December and January for the minor and major seasons, respectively [27]. These dry spells were normally accompanied by low night temperatures suggested to be conducive for flowering in mango [34].

The rate of development of Haden, Kent, Palmer, and Keitt mango fruits appeared to take the form of a simple sigmoid pattern.

\section{Conclusions}

In each case of Haden, Kent, Palmer, and Keitt varieties, physical fruit development attributes established as standard harvest maturity values were: weight (640 g, 836 g, $837 \mathrm{~g}$, and $1104 \mathrm{~g}$, respectively), length $(16.31 \mathrm{~cm}, 16.19 \mathrm{~cm}, 21.22$ $\mathrm{cm}$, and $19 \mathrm{~cm}$, respectively), width $(30.97 \mathrm{~cm}, 33.47 \mathrm{~cm}, 30.86 \mathrm{~cm}$, and 35.91 $\mathrm{cm}$, respectively), volume $\left(598 \mathrm{~cm}^{3}, 807 \mathrm{~cm}^{3}, 772 \mathrm{~cm}^{3}\right.$, and $959 \mathrm{~cm}^{3}$, respectively), density $\left(1.147 \mathrm{~g} / \mathrm{cm}^{3}, 1.076 \mathrm{~g} / \mathrm{cm}^{3}, 1.084 \mathrm{~g} / \mathrm{cm}^{3}\right.$, and $1.189 \mathrm{~g} / \mathrm{cm}^{3}$, respectively), and indentation $(0.25 \mathrm{~cm}, 0.49 \mathrm{~cm}$, and $0.50 \mathrm{~cm}$, respectively). The intensity of grooves around the stylar-scar end of Palmer fruits was studied and used as maturity index. Index values of $0.075 \mathrm{mls}, 0.150 \mathrm{mls}, 0.425 \mathrm{mls}$, and $0.116 \mathrm{mls}$, respectively, for Haden, Kent, Palmer, and Keitt varieties were recorded as latex exuded at harvest since these values tallied with the other physical harvest maturity index values, and also with those of rain fall and temperature values.

Rain fall data range of 480.36 - $564.68 \mathrm{~mm}$ was established for the development of Haden and Kent fruits while a range of 564.68 - $608.55 \mathrm{~mm}$ was established for the development of Kent, Palmer, and Keitt mango fruits for the major season; with Kent fruits performing favourably at all the two rainfall data ranges. For the minor season, a range of $469.80-529.03 \mathrm{~mm}$ of the accumulated rainfall data was established for Haden and Kent mango fruits while a range of 529.03 $567.25 \mathrm{~mm}$ was established for Kent, Palmer, and Keitt mango fruits; with Kent 
fruits growing favourably at both rainfall ranges.

Temperature range of $3850.9^{\circ} \mathrm{C}-4203.3^{\circ} \mathrm{C}$ heat units was established for optimum development of Haden and Kent fruits while a range of $4203.3^{\circ} \mathrm{C}$ $4554.7^{\circ} \mathrm{C}$ was established for the growth of Kent, Palmer, and Keitt mango fruits for the major season; with Kent fruits growing favourably at all the two temperature ranges. For the minor season, a range of $3305.8^{\circ} \mathrm{C}-4007.2^{\circ} \mathrm{C}$ was established for Haden and Kent mango fruits while a range of $4007.2^{\circ} \mathrm{C}-4409.0^{\circ} \mathrm{C}$ was established for Kent, Palmer, and Keitt mango fruits; with Kent fruits growing favourably at both temperature ranges.

Temperature, rainfall, and physical characteristics are therefore important non-destructive criteria for fixing maturity index values for mango fruits.

\section{Acknowledgements}

The authors are thankful to the manager of Prudent Export and Import Company Limited Mango Plantation in the Somanya-Dodowa mango production zone of the Dangme West District of Greater Accra Region, Ghana.

\section{Conflicts of Interest}

The authors declare no conflicts of interest regarding the publication of this paper.

\section{References}

[1] Okorley, E.L., Acheampong, L. and Abenor, M.T. (2014) The Current Status of Mango Farming Business in Ghana: A Case Study of Mango Farming in the Dangme West District. Ghana Journal of Agricultural Science, 47, 1-2.

[2] CBI (2019) Centre for the Promotion of Imports from Developing Countries. IATI Identifier: NL-KVK-27378529-25403_2.

[3] Zakari, A.K. (2012) Ghana National Mango Study. https://www.scribd.com/document/211496488/National-Mango-Study-Ghana

[4] EUSMG (2001) European Union Strategic Marketing Guide. Fresh Fruit and Vegetables, $1,48$.

[5] Abu, M., Olympio, N.S., Darko, J.O., Adu-Amankwa, P. and Dadzie, B.K. (2010) The Mango Industry in Ghana. Ghana Journal of Horticulture, 9, 135-147.

[6] Marques, E.J.N., De Freitas, S.T., Pimentel, M.F. and Pasquini, C. (2016) Rapid and Non-Destructive Determination of Quality Parameters in the "Tommy Atkins" Mango Using a Novel Handheld near Infrared Spectrometer. Food Chemistry, 197, 1207-1214. https://doi.org/10.1016/j.foodchem.2015.11.080

[7] Kouno, Y., Mizuno, T., Maeda, H., Akinaga, T., Tandbe, T. and Kohda, Y. (1994) Feasibility Studies into NIR Technique for Measurement of Internal Quality of Some Tropical Fruits. In: Champ, B.R., Highley, E. and Johnson, G.I., Eds., Postharvest Handling of Tropical Fruits, ACIAR Proceedings-50, Canberra, 385-387.

[8] Hatfield, J.L. and Prueger, J.H. (2015) Temperature Extremes: Effect on Plant Growth and Development. Journal of Weather Climate Extremes, 10, 4-10. https://doi.org/10.1016/j.wace.2015.08.001

[9] Parjane, M.A., Gajanan, D.V., Ramdas, G.D. and Mahadev, J.S. (2015) Quality Evo- 
lution of Mangifera indica Using Non-Destructive Method. International Journal of Engineering Research and General Science, 3, 71-76.

[10] Nagle, M., Intani, K., Romano, G., Mahayothee, B., Sardsud, V. and Müller, J. (2016) Determination of Surface Color of "All Yellow" Mango Cultivars Using Computer Vision. International Journal of Agricultural and Biological Engineering, 9, 42-50.

[11] Manasa, B., Jagadeesh, S.L., Thammaiah, N. and Nethravathi (2019) Colour Measurement of Ripening Mango Fruits as Influenced by Pre-Harvest Treatments Using $\mathrm{L}^{\star}, \mathrm{a}^{\star}, \mathrm{b}^{\star}$ Coordinates. Journal of Pharmacognosy and Phytochemistry, 8, 2466-2470.

[12] Sharma, R.R. and Krishna, K.R. (2017) Non-Destructive Evaluation of Jelly Seed Disorder in Mango. Division of Food Science and Postharvest Technology. ICAR-IARI, New Delhi.

[13] Penchaiya, P., Tijskens, L.M.M., Uthairatanakij, A., Srilaong, V., Tansakul, A. and Kanlayanarat, S. (2020) Modelling Quality and Maturity of "Namdokmai Sithong" Mango and Their Variation during Storage. Journal of Postharvest Biology and Technology, 159, Article No. 11000.

https://doi.org/10.1016/j.postharvbio.2019.111000

[14] Chen, L.Y., Wong, D.M., Fang, C.Y., Chiu, C.I., Chou, T.I., Wu, C.C., Chiu, S.W. and Tang, K.T. (2018) Development of an Electronic-Nose System for Fruit Maturity and Quality Monitoring. 2018 IEEE International Conference on Applied System Invention (ICASI), Chiba, 13-17 April 2018.

[15] GEPA (2018) Mango-GEPA Buyer Portal. GEPA Sector Profile of Mangoes from Ghana-Sector Capabilities, Reasons to Buy, Trade Performance, Featured Exporters, and Useful Links. https://www.gepaghana.org

[16] Thompson, A.K. and Burden, O.J. (1995) Harvesting and Fruit Care. In: Gowen, S., Ed., Bananas and Plantains, World Crop Series, Springer, Dordrecht, 403-433. https://doi.org/10.1007/978-94-011-0737-2 14

[17] Dadzie, B.K. and Orchard, J.E. (1997) Routine Post-Harvest Screening of Banana/Plantain Hybrids: Criteria and Methods. INIBAP Technical Guidelines 2. International Plant Genetic Resources Institute, Rome, International Network for the Improvement of Banana and Plantain, Montpelier, ACP-EU Technical Centre for Agricultural and Rural Cooperation, Wageningen, 63.

[18] Iqbal, M. (2001) All About/Orchards/Mangoes. Post-Harvest Handling of Mangoes. https://www.2001-2006Pakissan.com

[19] Kader, A.A., Kasmire, R.F., Mitchell, F.G., Reid, M.S., Sommer, N.F. and Thompson, J.F. (1985) Postharvest Technology of Horticultural Crops. Special Publication No. 3311. Division of Agriculture and Natural Resources, University of California, Davis.

[20] Snedecor, G.W. and Cochran, W.G. (1980) Statistical Methods. 7th Edition, Iowa State University Press, Ames, 507.

[21] Nandi, C.S., Tudu, B. and Koley, C. (2014) Machine Vision Based Techniques for Automatic Mango Fruit Sorting and Grading Based on Maturity Level and Size. In: Sensing Technology: Current Status and Future Trends II, Springer International Publishing, Berlin, 27-46. https://doi.org/10.1007/978-3-319-02315-1 2

[22] Naik, S., Patel, B. and Pandey, R. (2015) Shape, Size, and Maturity Features Extraction with Fuzzy Classifier for Non-Destructive Mango (Mangifera indica L., cv. Kesar) Grading. IEEE Technological Innovation in ICT for Agriculture and Rural De- 
velopment (TIAR), Chennai, 10-12 July 2015, 1-7. https://doi.org/10.1109/TIAR.2015.7358522

[23] Zhang, B., Huang, W., Li, J., Zhao, C., Fan, S., Wu, J. and Liu, C. (2014) Principles, Developments, and Applications of Computer Vision for External Quality Inspection of Fruits and Vegetables: A Review. Food Research International, 62, 326-343. https://doi.org/10.1016/j.foodres.2014.03.012

[24] Raut, K. and Bora, V. (2016) Assessment of Fruit Maturity Using Digital Image Processing. International Journal of Science and Technology Engineering, 3, 273-279.

[25] Singh, B., Singh, H., Chakraborty, I., Panja, P. and Hynniewta, L. (2014) Physicochemical Properties of Three Commercial Varieties of Mango (Mangifera indica L.) in West Bengal. National Seminar on Integrated Approaches in Horticulture for Sustainable Development, Visva-Bharati.

[26] CODEX STAN 184-1993 (2005) Codex Standard for Mangoes (Mangifera indica L.). Codex Alimentarius Commission, Volume 5B-1993, Joint FAO/WHO Food Standards Programme. https://www.fao.org/input/dowloads/315/CXS 184e.pdf

[27] Abu, M. (2010) Quality Criteria for Mango Export in Ghana. PhD Thesis Submitted to the School of Graduate Studies. Kwame Nkrumah University of Science and Technology, Kumasi, 172 p.

[28] Krishnapillai, N. and Wijeratham, W.R.S. (2016) Sap Burn Management of Mangoes (Mangifera indica L.) in Sri Lanka. Pakistan Journal of Botany, 48, 2147-2152.

[29] Mazhar, M.S., Amin, M., Malik, U.A., Campbell, J. and Johnson, P. (2011) Improved Harvest and Desapping Practices Affect Mango Fruit Quality along the Supply Chain. International Journal of Agriculture and Biology, 13, 776-780.

[30] Barman, K., Asrey, R., Pal, R.K., Jha, S.K. and Sharma, S. (2015) Influence of Different Desapping Agents on the Incidence of Sapburn, Ripening Behaviour, and Quality of Mango. Journal of Food Science Technology, 51, 161-170. https://doi.org/10.1007/s13197-013-0995-x

[31] Parthasarathy, S. (2014) Sap-Injury in Mango and Their Management. https://www.krishisewa.com/articles

[32] Iqbal, M. (2015) Post-Harvest Handling of Mangoes. https://www.pakissan.com/english

[33] Ledesma, N., Richard, J., Campbell and Wasielewski, J. (2016) Training and Pruning a Mango Orchard to Improve Blooming and Yield in South Florida. Florida State Horticultural Society, Volume 129, 14-16. https://www.researchgate.net/publication/315031941

[34] Litz, R.E. (2003) The Mango: Botany, Production, and Uses. Tropical Research and Education Centre. University of Florida, USA. CABI Publishing, CAB International, Wallingford, 587.

[35] Slaven, T. (2017) Spacing, Soil Preparation, and Planting Mangoes. https://www.agric.wa.gov.au/mangoes/spacing-soil-preparation-and-planting-mang $\underline{\text { oes }}$ 